the late 1960s, he generously supported Ryle's synthesized aerial at Cambridge even though this meant abandoning his own cherished ambition for a thousandfoot telescope. But despite his involvement in so many national issues and recurring budget cuts, Lovell continued over the years to update and extend the facilities at Jodrell Bank, culminating in the multitelescope interferometer which has vastly improved the resolution available. Manchester University now has a research centre which will keep it in the forefront of radioastronomy for many years, an

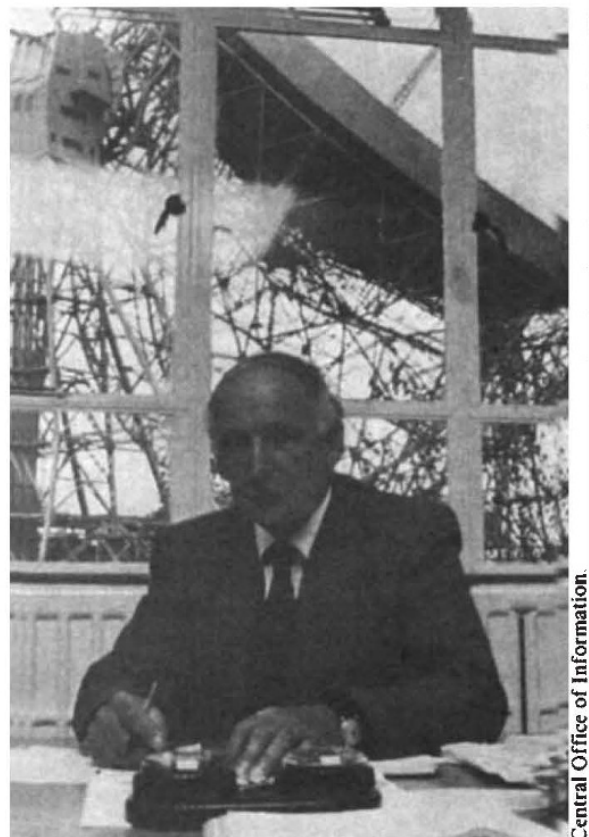

Man and machine - Bernard Lovell at Jodrell Bank, 1977, with the telescope in the background.

impressive monument to one man's ability, ingenuity and dogged determination.

Apart from giving his readers a portrait of Lovell, in this book Saward provides a valuable insight into the efforts necessary nowadays to bring about a major scientific advance. It is no longer sufficient to convince one's peers of the scientific merits of a particular project. These have to be explained in terms which a layman can appreciate. Allies have to be courted, doubters converted and critics confounded. Expenditure must be justified against competing projects and the campaign will need to be sustained for many years.

The biography concludes with Lovell's retirement in 1980 as Professor of Radioastronomy at Manchester. But this cannot be the end of the story - it somehow seems unlikely that he will be content to pass his lime cultivating the garden, playing the piano and watching cricket, his leisure interests listed in Who's Who.

From 1939 to 1945 Sir Robert Cockburn worked on radar at the Telecommunications Research Establishment, Malvern. He was later Chief Scientist of the Ministry of Aviation and Director of the Royal Aircraft Establishment, Farnborough.

\section{The bomb and the bumble-bees}

\section{Walter Gratzer}

\section{Late Night Thoughts. *}

By Lewis Thomas.

Oxford University Press: 1984. Pp.175. £9.95.

"Is ditchwater dull? Naturalists with microscopes have told me it teems with quiet fun." Thus G.K. Chesterton, and his words could serve as a text for some of Lewis Thomas's best essays. This, his third collection, will not disappoint his devotees, who will find here the familiar blend of reminiscence and reflection, the excursions into etymology, and withal an artful simplicity of style, illuminated by periodic shafts of startling insight. Thomas descants on health care, the funding of science and the nuclear arms race; he ruminates on the march of molecular biology, on natural history and the benefits of biomedical research. One of the threads that runs through his discourse is his entrancement with the intricacies of nature; Thomas sees the Earth as a kind of exquisitely crafted, bejewelled Fabergé egg,

the loveliest object afloat round the sun, enclosed in its own blue bubble of atmosphere, manufacturing and breathing its own oxygen, fixing its own nitrogen from the air into the soil, generating its own weather at the surface of its rain forests, constructing its own carapace from living parts.

There is touch of mysticism here, as also elsewhere, for example in his fascination with the mind of the bee.

The second thread that runs through the book is a bracing optimism about science, present and future - the only game in town, Thomas calls it - with perhaps even a hint of hubris; the problems engendered by science, he believes, will be put right by scientists, iatrogenic diseases cured by doctors. He even has a good word for the embattled discipline of sociology, which he expects soon to see emerge as an exact science.

These robust views contrast oddly with his dark perception of a future with the Bomb. Brooding on the unthinkable, he gives vent to the following: "If I were very young, sixteen or seventeen years old, I think I would begin, perhaps very slowly and imperceptibly, to go crazy". Thomas is not, to my mind, at his best in this rhetorical vein; what one looks for from a writer and scientist of his stature is something more reasoned that an evocation of the horrors of Hiroshima: Freeman Dyson, in his admirable series of articles in the New Yorker (now a book), showed that it can be

*In the United States Late Night Thoughts on Listening to Mahler's Ninth Symphony, published by Viking, $\$ 12.95$. done with no loss of impact. But as that eupeptic divine, Sydney Smith remarked about his own meditations on the human condition, cheerfulness will keep breaking in; Thomas proposes, as a safeguard against nuclear war, huge armies of conscript hostages, American and Russian, to be kept in perpetual motion across each others' countries, lodged in luxurious Pullman trains, full of beer, running to undisclosed timetables. Such travel would both broaden the minds of the soldiery and restore the railways to solvency, while ensuring that no missile ever leaves its launching pad.

The book abounds in such jeux d'esprit. Thomas's imagination is caught, for example, by the biology of the lie-detector: if the telling of a lie causes sufficient anxiety that it should reveal itself in a measurable physiological change, he wonders, are there perhaps other manifestations, such as secretion of a peptide or some other product from the skin, that could be detected and quantitated by microanalytical techniques? And is there then a genetic basis for the ethical imperative, a biochemical morality? Dr Thomas explores with some relish the social consequences that such a discovery might bring in its train. (Ambrose Bierce, on the other hand, defines conscience as a small, still voice that warns you that someone may be watching.)

Many of these essays will serve splendidly for starting dinner-table conversations; the "Seven Wonders of the Modern World", for instance, should be a diverting game to play (even though $\mathrm{Dr}$ Thomas's first nomination - the bacterium that was supposed to thrive at $250^{\circ} \mathrm{C}$ under pressure in thermal vents under the Pacific Ocean - has already been exposed for an illusion, due probably to contamination by a less aristocratic organism).

Thomas's purpose is also more serious, however, for he does not address himself only or even primarily to scientists. I do not believe there is anyone writing today who better represents to the outside world how basic and applied research, and indeed scientists, function. He makes clear for example the essential unpredictability of the process of discovery. It was the organic chemist, Homer Adkins, who defined basic research as shooting an arrow into the air, and where it lands painting the target. The implications of this truth have urgently to be brought home to our paymasters, the public, and their none-too-obedient servants, the politicians. Let us hope Late Night Thoughts falls into the hands of some of the more literate of them and that some of the lessons penetrate their preconceptions. The rest of us will settle for the continuing stimulation and entertainment that Dr Thomas so gracefully affords.

Walter Gratzer is in the Medical Research Council's Cell Biophysics Unit, King's College, University of London. 